\title{
Mild Increases in Plasma Creatinine after High-Risk Abdominal Surgery Are Associated with Long-Term Renal Injury: A Retrospective Cohort Study
}

Alexandre JOOSTEN ( $\nabla$ joosten-alexandre@hotmail.com )

Hopital Bicetre https://orcid.org/0000-0002-5214-4589

Brigitte Ickx

Erasme Hospital: Hopital Erasme

ZAKARIA Mokhtari

Erasme Hospital: Hopital Erasme

Luc Van Obbergh

Erasme Hospital: Hopital Erasme

Valerio Lucidi

Erasme Hospital: Hopital Erasme

Vincent Collange

Médipôle Lyon-Villeurbanne: Medipole Lyon-Villeurbanne

Salima Naili

Hospital Paul Brousse: Hopital Paul Brousse

Philippe Ichai

Hospital Paul Brousse: Hopital Paul Brousse

Didier Samuel

Hospital Paul Brousse: Hopital Paul Brousse

Sa Cunha Antonio

Hospital Paul Brousse: Hopital Paul Brousse

Brenton Alexander

University of California San Diego

Matthieu Legrand

University of California San Francisco

Fabio Silvio Taccone

Erasme Hospital: Hopital Erasme

Anatole Harrois

Hospital Bicetre: Hopital Bicetre

Jacques Duranteau

Hospital Bicetre: Hopital Bicetre

Jean-Louis Vincent 
Erasme Hospital: Hopital Erasme

Joseph Rinehart

University of California Irvine

Philippe Van der Linden

CHU Brugmann - Site Victor Horta: UVC Brugmann - Site Victor Horta

\section{Research article}

Keywords: Acute kidney disease, Chronic kidney disease, Perioperative, Dialysis, Follow-up, Postoperative complications

Posted Date: November 9th, 2020

DOI: https://doi.org/10.21203/rs.3.rs-102670/v1

License: (c) (1) This work is licensed under a Creative Commons Attribution 4.0 International License. Read Full License 


\section{Abstract}

Background: The impact of mild acute kidney injury (AKI) observed in the immediate postoperative period after major surgery on long term renal function remains poorly defined. According to the "Kidney Disease: Improving Global Outcomes" (KDIGO) classification, a mild injury corresponds to a KIDIGO stage 1, characterized by an increase in creatinine of at least $0.3 \mathrm{mg} / \mathrm{dl}$ within a 48-hour window or 1.5 to 1.9 times the baseline level within the first week post-surgery. We tested the hypothesis that patients who underwent moderate-to high-risk abdominal surgery and developed mild AKI in the following days would be at an increased risk of long-term renal injury compared to patients with no postoperative AKI.

Methods: In this single centre retrospective study, all consecutive adult patients with a plasma creatinine value $\leqq 1.5 \mathrm{mg} / \mathrm{dl}$ who underwent high-risk abdominal surgery between 2014-2019 and who had at least three recorded creatinine measurements (before surgery, during the first seven postoperative days, and at long-term follow up [6 months-2 years]) were included. AKI was defined using a "modified" (without urine output criteria) KDIGO classification as mild (stage 1 characterised by an increase in creatinine of $\geq 0.3$ $\mathrm{mg} / \mathrm{dl}$ within 48-hours or 1.5-1.9 times baseline) or moderate-to-severe (stage 2-3 characterised by increase in creatinine 2 to 3 times baseline or to $\geq 4.0 \mathrm{mg} / \mathrm{dl}$ ). Development of long-term renal injury was compared in patients with and without postoperative AKI

Results: Among the 815 patients included, 109 (13.4\%) had postoperative AKI (81 mild [KDIGO 1] and 28 moderate-to-severe [KDIGO 2-3]). The median long-term follow-up was 360, 354 and 353 days for the three groups respectively $(P=0.190)$. Patients who developed mild AKI had a higher risk of long-term renal injury than those who did not (odds ratio 3.1 [95\% Cl 1.7-5.5]; $\mathrm{P}<0.001$ ). In multivariable analysis, mild postoperative AKI was independently associated with an increased risk of developing long-term renal injury (adjusted odds ratio 4.5 [95\% $\mathrm{Cl} 1.8-11.4] ; \mathrm{P}=0.002$ ).

Conclusions: Mild AKI after high-risk abdominal surgery is associated with a higher risk of long-term renal injury one year after surgery.

\section{Background}

Acute kidney injury (AKI) occurs frequently in patients after major surgeries [1-3]. Most data regarding AKI outcomes have come from critically ill patients or postoperative vascular and cardiac patients [4-12]. In these study populations, AKI has consistently been reported to be associated with increased lengths of hospital stay, higher readmission rates and greater healthcare costs [12-15]. Development of AKI in these patients has also been associated with altered short and long-term clinical outcomes, including death [10, 16].

One of the most common systems used to diagnose AKI is the "Kidney Disease: Improving Global Outcomes" (KDIGO) classification, in which kidney dysfunction is based on changes in serum creatinine and urine output [17]. However, as urine output is rarely accurately measured in the perioperative setting, postoperative AKI is frequently assessed based on an increase in serum creatinine alone. Mild kidney 
injury is more frequent than moderate or severe injury after a major surgical procedure. Unfortunately, these three stages are generally combined into a global composite of "AKI", ignoring the obvious differences in incidence and severity across the stages. Moreover, many clinicians (surgeons, intensivists and anaesthesiologists), routinely under-recognise the importance of mild AKI, [18] as they often consider postoperative AKI to be a transient phenomenon without short or long-term consequences [19]. However, Turan et al. recently reported that mild postoperative AKI could affect long-term renal function in patients who had had various non-cardiac surgical procedures [20]. Nevertheless, there is limited specific literature regarding the long-term renal consequences of mild AKI after major abdominal surgery [19-21].

We therefore conducted a retrospective cohort study to analyse the association between postoperative AKI and long-term renal injury after high-risk abdominal surgery. We hypothesised that patients with a slight increase in their postoperative plasma creatinine, corresponding to mild AKI, would be at higher risk of long-term renal injury compared to patients without postoperative creatinine increase.

\section{Methods}

The Ethics Committee of Erasme, Brussels, Belgium on February 10th, 2020, approved this single centre retrospective cohort analysis (Reference: P2020/031). Data collection was performed by Z.M in our institution between February 11th and April 1st 2020.

We included all consecutive adult patients ( $\geq 18$ years old) who:

1) had undergone elective high-risk abdominal surgery (including hepatobiliary surgery, pancreatectomy, gastrectomy, oesophagectomy, cancer debulking, and cystectomy) under general anaesthesia between January 1st, 2014, and April 30th, 2019. Patients who had had major vascular surgery were also included if the surgery involved an abdominal incision (e.g., aorto bifemoral bypass and abdominal aortic aneurysm surgery);

2) had a plasma creatinine value measured before surgery, within 7 days after surgery, and at a later follow up visit (6 months to 2 years after surgery).

Patients who received dialysis in the preoperative period, those with chronic kidney disease (predefined as a baseline creatinine level $>1.5 \mathrm{mg} / \mathrm{dl}$ ), those who had emergency surgery and patients who had another surgical procedure in the two years following their first surgery (unless it was a redo surgery in the same admission) were excluded. Patients who had suprarenal clamping during their vascular surgery were also excluded as this clamping phase can seriously impact renal function.

For each eligible patient, we recorded, from our hospital health records, the plasma creatinine concentration prior to surgery (the most recent result available in the three months before surgery), the highest creatinine concentration during the seven postoperative days, and the creatinine concentration at long-term follow up (between 6 months and 2 years; if multiple creatinine values were available, the 
measurement closest to one year following surgery was always selected). If no long-term creatinine measurement was available in the hospital database, attempts were made to contact the patients and/or their general practitioners to obtain any values that had been measured elsewhere.

The change in creatinine concentration between the preoperative and the postoperative period was used to classify patients according to a "modified" KDIGO classification in which the urine output criteria were not considered [17]. Mild AKI (KDIGO stage 1) was characterised by an increase in creatinine of $\geq$ $0.3 \mathrm{mg} / \mathrm{dl}$ within 48-hours or 1.5-1.9 times baseline; moderate AKI (KDIGO stage 2) by an increase in creatinine of 2-2.9 times baseline; and severe (KDIGO stage 3) was characterised by an increase in creatinine 3 times baseline or to $\geq 4.0 \mathrm{mg} / \mathrm{dl}$ ). To simplify our statistical analysis because of the low occurrence rate, AKI stages 2 and 3 were combined into a single category (2-3), leaving us with three final groups (no AKI vs AKI stage 1 vs AKI stage 2-3).

Long-term renal injury was defined using the difference between the preoperative creatinine concentration and the long-term follow-up measurement. We used the same KDIGO classification system to stage longterm renal injury as we used for the immediate postoperative period.

\subsection{Statistical Analysis}

Distribution of continuous data was analysed using a Kolmogorov-Smirnov test. Normally distributed data are presented as means \pm standard deviation and were compared between groups using a one-way analysis of variance. Non-normally distributed data are presented as medians (interquartiles ranges) and were compared using a Kruskall-Wallis test. Dichotomous variables are presented as crude numbers and percentages and were compared between groups using a Chi-square test. Modelling of the risk of longterm renal injury was performed using the same approach as Turan et al [20] including early AKI and all covariates listed in Tables 1 and 2 in a logistic (binomial) model. The risk of developing long-term renal injury is presented as an odds ratio with $95 \%$ confidence intervals. Statistical analyses were done using Minitab 16 (Paris, France and Medcalc Software LTD, Ostend, Belgium) and R (www.r-project.org) 
Table 1

Patient Characteristics by acute kidney injury status

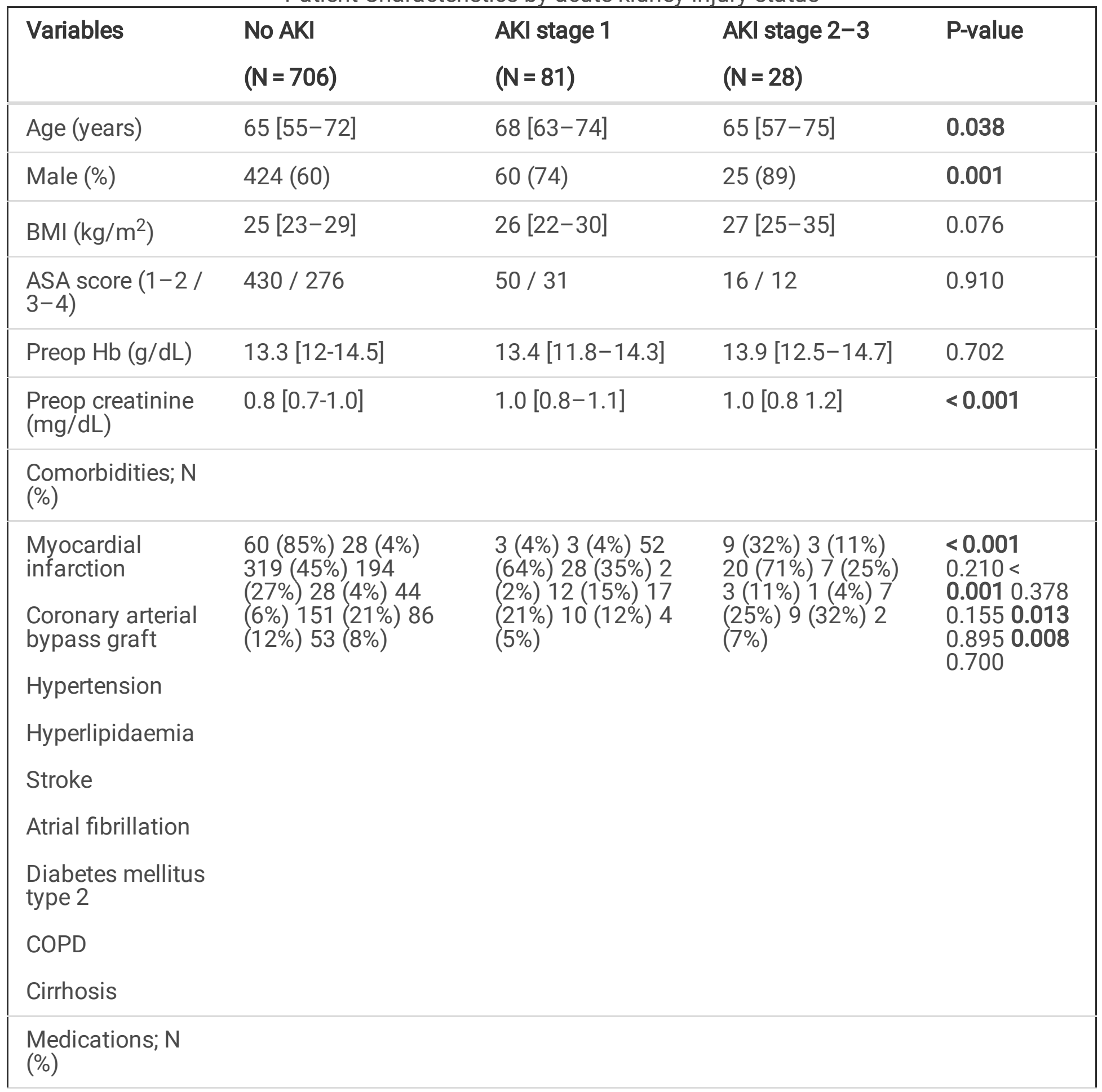

Values are presented as medians [interquartiles ranges] or numbers (percentages \%).

Abbreviation: COPD: chronic obstructive pulmonary disease; AKI: acute kidney injury - BMI: body mass index - preop: preoperative - ACEI: Angiotensin-converting-enzyme inhibitor - ARB: Angiotensin II receptor blocker - Hb: haemoglobin - ASA: American Society of Anesthesiologists

* included: gastrectomy, open colectomy nephrectomy, surrenalectomy, prostatectomy) 


\begin{tabular}{|c|c|c|c|c|}
\hline Variables & $\begin{array}{l}\text { No AKI } \\
(\mathrm{N}=706)\end{array}$ & $\begin{array}{l}\text { AKI stage } 1 \\
(\mathrm{~N}=81)\end{array}$ & $\begin{array}{l}\text { AKI stage } 2-3 \\
(\mathrm{~N}=28)\end{array}$ & P-value \\
\hline $\begin{array}{l}\text { Aspirin } \\
\text { Clopidogrel } \\
\text { घ blocker } \\
\text { ACEI } \\
\text { ARB } \\
\text { Calcium channel } \\
\text { blocker } \\
\text { Diuretics } \\
\text { Statin } \\
\text { Oral } \\
\text { hypoglycaemic } \\
\text { drugs } \\
\text { Insulin } \\
\text { Oral } \\
\text { anticoagulation }\end{array}$ & $\begin{array}{l}236(33 \%) 32(5 \%) \\
166(24 \%) 135 \\
(19 \%) 47(7 \%) 113 \\
16 \%) 59(8 \%) 211 \\
30 \%) 111(16 \%) 56 \\
(8 \%) 65(9 \%)\end{array}$ & $\begin{array}{l}32(40 \%) 1(1 \%) \\
28(35 \%) 23(28 \%) \\
8(10 \%) 19(23 \%) \\
8(10 \%) 18(22 \%) \\
10(12 \%) 7(9 \%) 9 \\
(11 \%)\end{array}$ & $\begin{array}{l}8(29 \%) 3(11 \%) \\
13(46 \%) 11 \\
(39 \%) 3(11 \%) 7 \\
(25 \%) 8(29 \%) 12 \\
(43 \%) 4(14 \%) 2 \\
(7 \%) 3(11 \%)\end{array}$ & $\begin{array}{l}0.4580 .100 \\
0.0030 .007 \\
0.4260 .126 \\
0.0010 .105 \\
0.7180 .962 \\
0.834\end{array}$ \\
\hline $\begin{array}{l}\text { Type of Surgery } \\
(\mathrm{N})\end{array}$ & & & & 0.022 \\
\hline $\begin{array}{l}\text { Pancreatectomy } \\
\text { Hepatobiliary } \\
\text { Oesophagectomy } \\
\text { Cystectomy } \\
\text { Cancer debulking } \\
\text { Major aortic } \\
\text { vascular surgery } \\
\text { Other surgical } \\
\text { procedure * }\end{array}$ & $\begin{array}{l}155(22 \%) 189 \\
(27 \%) 75(11 \%) 63 \\
(\%) 32(5 \%) 144 \\
(20 \%) 48(7 \%)\end{array}$ & $\begin{array}{l}18(22 \%) 14(17 \%) \\
12(15 \%) 15(19 \%) \\
2(2 \%) 15(19 \%) 5 \\
(6 \%)\end{array}$ & $\begin{array}{l}3(11 \%) 3(11 \%) 3 \\
(11 \%) 7(25 \%) 2 \\
(7 \%) 9(32 \%) 1 \\
(4 \%)\end{array}$ & \\
\hline Values are present & as medians [interqu & $s$ ranges] or numb & s (percentages \%). & \\
\hline $\begin{array}{l}\text { Abbreviation: COP } \\
\text { index - preop: preo } \\
\text { receptor blocker - }\end{array}$ & $\begin{array}{l}\text { hronic obstructive p } \\
\text { ative - ACEl: Angiote } \\
\text { haemoglobin - ASA: }\end{array}$ & $\begin{array}{l}\text { onary disease; AKI: } \\
\text {-converting-enzyme } \\
\text { erican Society of An }\end{array}$ & $\begin{array}{l}\text { cute kidney injury - } \\
\text { nhibitor - ARB: Angi } \\
\text { sthesiologists }\end{array}$ & $\begin{array}{l}\text { Ml: body mass } \\
\text { ensin II }\end{array}$ \\
\hline
\end{tabular}


Table 2

Intraoperative variables by acute kidney injury status

\begin{tabular}{|c|c|c|c|c|}
\hline Variables & $\begin{array}{l}\text { No AKI } \\
(N=706)\end{array}$ & $\begin{array}{l}\text { AKI stage } 1 \\
(\mathrm{~N}=81)\end{array}$ & $\begin{array}{l}\text { AKI stage 2-3 } \\
(\mathrm{N}=28)\end{array}$ & $\begin{array}{l}\mathrm{P}- \\
\text { value }\end{array}$ \\
\hline $\begin{array}{l}\text { Anaesthesia duration ( } \\
\text { min) }\end{array}$ & $346[260-446]$ & $421[339-502]$ & $451[354-576]$ & $<0.001$ \\
\hline Surgery duration (min) & $262[184-352]$ & $337[263-397]$ & 366 [282-445] & $<0.001$ \\
\hline Total crystalloid (ml) & $\begin{array}{l}2000[1300- \\
3000]\end{array}$ & $\begin{array}{l}3000[2000- \\
4000]\end{array}$ & $\begin{array}{l}4000[2000- \\
5875]\end{array}$ & $<0.001$ \\
\hline Total colloid ${ }^{£}(\mathrm{ml})$ & $500[500-1000]$ & $1000[500-1500]$ & $1000[500-2000]$ & 0.008 \\
\hline Total blood product (ml) & $500[263-764]$ & $550[396-1683]$ & $525[270-1858]$ & 0.157 \\
\hline Total IN (ml) & $\begin{array}{l}2500[1800- \\
3500]\end{array}$ & $\begin{array}{l}3500[2500- \\
5374]\end{array}$ & $\begin{array}{l}4500[2275- \\
7313]\end{array}$ & $<0.001$ \\
\hline Estimated blood loss (ml) & 500 [200-1000] & 700 [300-1725] & $1000[463-1575]$ & $<0.001$ \\
\hline Diuresis (ml) & $300[150-500]$ & $300[175-500]$ & $310[160-496]$ & 0.862 \\
\hline Gastric suction (ml) & $100[50-100]$ & $50[50-100]$ & $50[50-163]$ & 0.668 \\
\hline TOTAL OUT (ml) & 913 [550-1600] & 1110 [750-2125] & 1375 [900-2188] & 0.002 \\
\hline Net fluid balance (ml) & 1510 [798-2353] & $\begin{array}{l}2300[1384- \\
3275]\end{array}$ & $\begin{array}{l}3125[1138- \\
5186]\end{array}$ & $<0.001$ \\
\hline Use of vasopressors, N (\%) & $554(78)$ & $67(83)$ & $23(82)$ & 0.619 \\
\hline \multicolumn{5}{|c|}{ Values are presented as medians [interquartiles ranges] or numbers (percentages \%). } \\
\hline 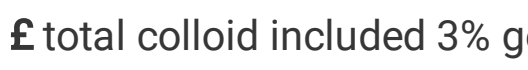 & 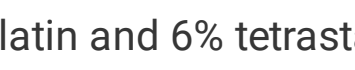 & & & \\
\hline
\end{tabular}

\section{Results}

Among the 1482 patients who underwent high-risk abdominal surgery between January 1st 2014 and April 30th 2019, 815 patients met the inclusion criteria and were thus included in our study. The main reason for exclusion was lack of postoperative or long-term creatinine values (Fig. 1).

Among the 81 patients who developed mild postoperative AKI, 19 patients (23.5\%) had persistent mild or moderate-to-severe renal injury one year after surgery, compared to $64(9.1 \%)$ of those who had no postoperative AKI $(\mathrm{P}<0.001)$ (Fig. 2). Among the 28 patients $(3.4 \%)$ who developed moderate to severe AKI postoperatively, 10 (35.7\%) had some degree of long-term renal dysfunction. Patients who developed mild AKI after surgery therefore had a threefold higher chance of developing long-term renal injury compared to patients without postoperative AKI (odds ratio [95\% Cl] of $3.1[1.7-5.5] ; \mathrm{P}=0.0001$ ). In 
patients with postoperative AKI KDIGO stage $2-3$, the odds ratio for development of long-term renal dysfunction was $5.6(95 \% \mathrm{Cl} 2.5-12.6 ; \mathrm{P}<0.0001)$.

Occurrence of postoperative AKI was associated with older age, higher baseline creatinine level and presence of comorbid conditions, notably a history of chronic hypertension, myocardial infarction, atrial fibrillation, or chronic obstructive pulmonary disease (Table 1). Patients who developed postoperative AKI had longer surgery times, received more fluid and had a higher estimated blood loss during surgery compared to patients without postoperative AKI (Table 2). Patients with postoperative AKI also had more postoperative complications and a longer hospital length of stay (Table 3). Importantly, long-term creatinine values were measured around one year in median among all groups (Table $3 ; P=0.190$ ) 
Table 3

Postoperative Variables by acute kidney injury status

\begin{tabular}{|c|c|c|c|c|}
\hline Variables & $\begin{array}{l}\text { No AKI } \\
(N=706)\end{array}$ & $\begin{array}{l}\text { AKI stage } \\
1 \\
(\mathrm{~N}=81)\end{array}$ & $\begin{array}{l}\text { AKI stage } \\
2-3 \\
(\mathrm{~N}=28)\end{array}$ & $\begin{array}{l}\mathrm{P}- \\
\text { value }\end{array}$ \\
\hline Length of stay in hospital (days) & $9[6-14]$ & $15[9-28]$ & $17[9-28]$ & $\dot{0} 001$ \\
\hline Creatinine max during the first POD\#7 (mg/dl) & $\begin{array}{l}0.8[0.7- \\
1.0]\end{array}$ & $\begin{array}{l}1.4[1.2- \\
1.7]^{-}\end{array}$ & $\begin{array}{l}2.8[1.8- \\
3.8]\end{array}$ & $\dot{0} 001$ \\
\hline Creatinine at hospital discharge & $\begin{array}{l}0.7[0.6- \\
0.9]\end{array}$ & $\begin{array}{l}1.0[0.8- \\
1.2]\end{array}$ & $\begin{array}{l}1.1[0.8- \\
1.5]\end{array}$ & ¿ 0.001 \\
\hline Creatinine at long-term follow up & $\begin{array}{l}0.9[0.7- \\
1.0]\end{array}$ & $\begin{array}{l}1.0[0.9- \\
1.2]\end{array}$ & $\begin{array}{l}1.1[0.9- \\
1.4]\end{array}$ & $\dot{0} 001$ \\
\hline $\begin{array}{l}\text { Measurement of long-term follow up creatinine } \\
\text { (days after surgery) }\end{array}$ & $\begin{array}{l}360[303- \\
393]\end{array}$ & $\begin{array}{l}354[298- \\
376]\end{array}$ & $\begin{array}{l}353[294- \\
386]\end{array}$ & 0.190 \\
\hline Minor complications; $\mathbf{N}(\%)$ & $146(21)$ & $36(44)$ & $14(50)$ & $\dot{0} 001$ \\
\hline Superficial wound infection & $19(3 \%)$ & $3(4 \%)$ & $0(0 \%)$ & \\
\hline Urinary infection & $33(5 \%)$ & $10(12 \%)$ & $5(18 \%)$ & \\
\hline Paralytic ileus & $20(3 \%)$ & $4(5 \%)$ & $5(18 \%)$ & \\
\hline Pneumonia & $13(2 \%)$ & $1(1 \%)$ & $2(7 \%)$ & \\
\hline Postoperative confusion & $20(3 \%)$ & $4(5 \%)$ & $3(11 \%)$ & \\
\hline Other infection & $72(10 \%)$ & $20(25 \%)$ & $7(25 \%)$ & \\
\hline Major complications; $\mathrm{N}(\%)$ & $101(14)$ & $27(33)$ & $11(39)$ & $\hat{0} .001$ \\
\hline Anastomotic leakage & $19(3 \%)$ & $5(6 \%)$ & $2(7 \%)$ & \\
\hline Peritonitis & $4(1 \%)$ & $1(1 \%)$ & $1(4 \%)$ & \\
\hline Sepsis & $22(3 \%)$ & $13(16 \%)$ & $5(18 \%)$ & \\
\hline Necrosis stoma & $8(1 \%)$ & $1(1 \%)$ & $0(0 \%)$ & \\
\hline Wound dehiscence & $9(1 \%)$ & $2(2 \%)$ & $1(4 \%)$ & \\
\hline Bleeding requiring a redo surgery & $24(3 \%)$ & $7(9 \%)$ & $1(4 \%)$ & \\
\hline Pulmonary embolism & $5(1 \%)$ & $1(1 \%)$ & $0(0 \%)$ & \\
\hline Pulmonary oedema & $7(1 \%)$ & $1(1 \%)$ & $1(4 \%)$ & \\
\hline
\end{tabular}

Values are medians [interquartiles rangees] or numbers (percentages \%). 


\begin{tabular}{|c|c|c|c|c|}
\hline Variables & $\begin{array}{l}\text { No AKI } \\
(N=706)\end{array}$ & $\begin{array}{l}\text { AKI stage } \\
1 \\
(\mathrm{~N}=81)\end{array}$ & $\begin{array}{l}\text { AKI stage } \\
2-3 \\
(\mathrm{~N}=28)\end{array}$ & $\begin{array}{l}\mathrm{P}- \\
\text { value }\end{array}$ \\
\hline Acute coronary syndrome & $0(0 \%)$ & $1(1 \%)$ & $0(0 \%)$ & \\
\hline Atrial fibrillation / arrhythmia & $15(2 \%)$ & $4(5 \%)$ & $1(4 \%)$ & \\
\hline Stroke & $0(0 \%)$ & $0(0 \%)$ & $0(0 \%)$ & \\
\hline Renal replacement therapy & $0(0 \%)$ & $0(0 \%)$ & $0(0 \%)$ & \\
\hline Reoperation & $35(5 \%)$ & $10(12 \%)$ & $3(11 \%)$ & \\
\hline 30-day mortality & $0(0 \%)$ & $0(0 \%)$ & $0(0 \%)$ & NA \\
\hline
\end{tabular}

In multivariable analysis, development of postoperative AKI was independently associated with long-term renal injury (adjusted odds ratio $[95 \% \mathrm{Cl}]$ of 4.5 [1.8-11.4]; $\mathrm{P}=0.002$ ) (Table 4).

Table 4

Significant independent variables predicting long-term kidney injury in multivariable model

\begin{tabular}{|llll|}
\hline Variables & Adjusted odds ratio & {$[95 \% \mathrm{Cl}]$} & P-value \\
\hline Postop AKI & 4.5 & {$[1.8-11.4]$} & 0.002 \\
\hline ASA score & 10.9 & {$[1.2-102.9]$} & 0.036 \\
\hline ARB & 0.07 & {$[0.0-0.7]$} & 0.027 \\
\hline LLAO & 4.9 & {$[1.1-22.1]$} & 0.037 \\
\hline Hepatectomy & 0.12 & {$[0.02-0.67]$} & 0.016 \\
\hline ASA: American Society of Anesthesiology physical status \\
\hline \multicolumn{4}{|l}{} \\
\hline ARB: angiotensin Il receptor blockers \\
\hline \multicolumn{4}{|l}{ LLAO: lower limb arteriopathy obliterans } \\
\hline
\end{tabular}

\section{Discussion}

In a cohort of 815 patients who underwent high-risk abdominal surgery, more than one fifth of patients (21\%) who developed mild postoperative AKI had mild renal injury long term, and $2.5 \%$ developed moderate to severe long-term renal injury. This observation demonstrates that even a slight increase in postoperative creatinine can be important and should not be neglected. Stated a different way, development of mild postoperative AKI more than tripled the odds of having renal injury one year after surgery compared to patients without postoperative AKI. 
Our results are in agreement with the only available study which examines the association of mild AKI with long-term renal injury [20]. This study, recently published by Turan et al, utilized a large database from the Cleveland Clinic that included more than 15,000 patients who underwent a variety of noncardiac surgical procedures ranging from low to high-risk. Interestingly, postoperative AKI was a complication in only $3 \%$ of their study population compared to $13.4 \%$ in our study. This is not surprising as we included only patients who had had high-risk abdominal surgery that carries a greater risk of postoperative renal dysfunction than low-risk abdominal surgery. Moreover, major surgery is a well-known contributing factor for postoperative AKI [22]. This increased risk is likely due to larger fluid shifts, blood losses and a relatively high incidence of perioperative hypotension in these patients, all of which can compromise renal blood flow [23-26]. Moreover, these types of surgical procedure are more often performed in elderly patients who are at a greater risk of having comorbidities that predispose to development of AKI.

As in the study by Turan et al., we used the KDIGO classification system to enable us to compare short and long-term renal function. Our study design allowed inclusion of all patients who had a creatinine measurement between six months and two years after surgery. However, the timing of the long-term measurement did not differ between the three groups and was very close to one year. Another recent study published by Mizota et al. demonstrated that even transient AKI after major abdominal surgery increased the risk of chronic kidney disease and one-year mortality.[19] Thus, even if a patient recovers from AKI within the first week after surgery, they should be considered at a greater risk of worse long-term outcome.

This study has some limitations that should be taken into consideration. Firstly, our study was observational, retrospective, and single-centre and included a relatively small sample size, largely because of the high proportion of patients without long-term follow up creatinine concentrations. Therefore, a causal relation cannot be proven. Secondly, we only included patients who underwent highrisk abdominal surgery [27] so that the data cannot be extrapolated to other types of surgery (neurosurgical, cardiac, etc). Thirdly, as urine output was not used for the AKI classification ("modified" KDIGO classification), this may have led to an "underestimation" of the incidence of postoperative AKI in our study cohort. Lastly, our logistic regression only took into account perioperative variables so that we did have information on specific events during the long-term follow-up (oncological evolution or cardiovascular problems).

\section{Conclusions}

Although mild increases in postoperative plasma creatinine concentration are frequently considered to have little long-term clinical significance, we found that patients undergoing high-risk abdominal surgery who developed a mild increase in plasma creatinine concentration had a much higher incidence of longterm renal dysfunction. Clinicians should not neglect "minor" disturbances in renal function after surgery as they may persist or even worsen during long-term follow up. The presence of even mild postoperative AKI may indicate a need for tighter follow up to monitor long-term renal function. 


\section{Abbreviations}

KDIGO

Kidney Disease:Improving Global Outcomes

AKI

acute kidney injury

\section{Declarations}

\section{Ethics approval and consent to participate:}

IRB approval (Reference: P2020/031). No Consent to participate needed for a retrospective study

Consent for publication: Not applicable

Availability of data and materials. By request to the corresponding author

\section{Competing interests.}

- Alexandre Joosten is consultants for Edwards Lifesciences (Irvine, California, USA), for Aguettant Laboratoire ( Lyon, France) and for Fresenius Kabi (Bad Homburg, Germany)

- Matthieu Legrand received research support from Shingotec (Hennigsdorf, Germany), lectures fees from Baxter (Guyancourt, France) and Fresenius Kabi (Bad Homburg, Germany), consulting fees from Novartis (Bâle, Switzerland)

- Philippe Van der Linden, has received, within the past 5 years, fees for lectures and consultancies from Fresenius GmbH (Bad Homburg, Germany), Aguettant SA (Lyon, France) and Nordic Pharma (Antwerpen, Belgium).

- Jean-Louis Vincent is Editor-in-Chief of Critical Care. He has no other conflicts related to this article.

- The other authors have no conflicts of interest related to this article.

Funding: The authors received no funding for this work

Authors' contributions. All authors read and approved the final manuscript.

- J: Study design and conception, data collection \& analysis and drafting the manuscript.

- I: Data collection and editing the final manuscript

- M: Data collection \& analysis and editing the final manuscript.

- VO: Data colection and editing the final manuscript.

- L: Data collection and editing the final manuscript.

- $\mathrm{N}$ : Data analysis and editing the final manuscript.

- I: Data analysis and editing the final manuscript. 
- S: Data analysis and editing the final manuscript.

- SC: Data analysis and editing the final manuscript

- A: Data collection and editing the final manuscript.

- L: Data analysis and editing the final manuscript.

- T: Data collection and editing the final manuscript.

- $\mathrm{H}$ : Data analysis and editing the final manuscript.

- D: Data analysis and editing the final manuscript.

- V: Data analysis and editing the final manuscript.

- R: Study design, statistical analysis and editing the final manuscript.

- VdL: Study design and conception, statistical analysis and editing the final manuscript.

Acknowledgements. All the anesthesia and surgical teams for the help in completing the electronic medical records of the patients.

\section{References}

1. O'Connor ME, Kirwan CJ, Pearse RM, Prowle JR. Incidence and associations of acute kidney injury after major abdominal surgery. 2016, 42(4):521-530.

2. Long TE, Helgason D, Helgadottir S, Palsson R, Gudbjartsson T, Sigurdsson GH, Indridason OS, Sigurdsson Ml. Acute Kidney Injury After Abdominal Surgery: Incidence, Risk Factors, and Outcome. Anesthesia analgesia. 2016;122(6):1912-20.

3. Ostermann M, Cennamo A, Meersch M, Kunst G. A narrative review of the impact of surgery and anaesthesia on acute kidney injury. Anaesthesia. 2020;75(Suppl 1):e121-33.

4. Harrois A, Grillot N, Figueiredo S, Duranteau J. Acute kidney injury is associated with a decrease in cortical renal perfusion during septic shock. 2018, 22(1):161.

5. Harrois A, Soyer B, Gauss T, Hamada S, Raux M, Duranteau J. Prevalence and risk factors for acute kidney injury among trauma patients: a multicenter cohort study. Crit Care (London England). 2018;22(1):344.

6. Sovik S, Isachsen MS, Nordhuus KM, Tveiten CK, Eken T: Acute kidney injury in trauma patients admitted to the ICU: a systematic review and meta-analysis. 2019, 45(4):407-419.

7. Forni LG, Darmon M, Ostermann M, Oudemans-van Straaten HM, Pettila V, Prowle JR, Schetz M, Joannidis M. Renal recovery after acute kidney injury. 2017, 43(6):855-866.

8. Brown JR, Hisey WM, Marshall EJ, Likosky DS, Nichols EL, Everett AD, Pasquali SK, Jacobs ML, Jacobs JP, Parikh CR. Acute Kidney Injury Severity and Long-Term Readmission and Mortality After Cardiac Surgery. Ann Thorac Surg. 2016;102(5):1482-9.

9. Ferreiro A, Lombardi R. Acute kidney injury after cardiac surgery is associated with mid-term but not long-term mortality: A cohort-based study. 2017, 12(7):e0181158. 
10. Hobson CE, Yavas S, Segal MS, Schold JD, Tribble CG, Layon AJ, Bihorac A. Acute kidney injury is associated with increased long-term mortality after cardiothoracic surgery. Circulation. 2009;119(18):2444-53.

11. Huber M, Ozrazgat-Baslanti T, Thottakkara P, Scali S, Bihorac A, Hobson C. Cardiovascular-Specific Mortality and Kidney Disease in Patients Undergoing Vascular Surgery. JAMA surgery. 2016;151(5):441-50.

12. Hobson C, Lysak N, Huber M, Scali S, Bihorac A. Epidemiology, outcomes, and management of acute kidney injury in the vascular surgery patient. J Vasc Surg. 2018;68(3):916-28.

13. Huber M, Ozrazgat-Baslanti T, Thottakkara P, Efron PA, Feezor R, Hobson C, Bihorac A. Mortality and Cost of Acute and Chronic Kidney Disease after Vascular Surgery. Ann Vasc Surg. 2016;30:7281.e71-72.

14. Kork F, Balzer F, Spies CD, Wernecke KD, Ginde AA, Jankowski J, Eltzschig HK. Minor Postoperative Increases of Creatinine Are Associated with Higher Mortality and Longer Hospital Length of Stay in Surgical Patients. Anesthesiology. 2015;123(6):1301-11.

15. Zarbock A, Koyner JL, Hoste EAJ, Kellum JA. Update on Perioperative Acute Kidney Injury. Anesthesia analgesia. 2018;127(5):1236-45.

16. Liano F, Felipe C, Tenorio MT, Rivera M, Abraira V, Saez-de-Urturi JM, Ocana J, Fuentes C, Severiano S. Long-term outcome of acute tubular necrosis: a contribution to its natural history. Kidney international. 2007;71(7):679-86.

17. Kellum JA, Lameire N. Diagnosis, evaluation, and management of acute kidney injury: a KDIGO summary (Part 1). Crit Care (London England). 2013;17(1):204.

18. Meersch M, Schmidt C, Zarbock A. Perioperative Acute Kidney Injury: An Under-Recognized Problem. Anesthesia analgesia. 2017;125(4):1223-32.

19. Mizota T, Dong L, Takeda C, Shiraki A, Matsukawa S, Shimizu S, Kai S. Transient acute kidney injury after major abdominal surgery increases chronic kidney disease risk and 1-year mortality. J Crit Care. 2019;50:17-22.

20. Turan A, Cohen B, Adegboye J, Makarova N, Liu L, Mascha EJ, Qiu Y, Irefin S, Wakefield BJ, Ruetzler K, et al: Mild Acute Kidney Injury after Noncardiac Surgery Is Associated with Long-term Renal Dysfunction: A Retrospective Cohort Study. Anesthesiology 2020.

21. Kim CS, Bae EH, Ma SK, Kweon SS, Kim SW. Impact of Transient and Persistent Acute Kidney Injury on Chronic Kidney Disease Progression and Mortality after Gastric Surgery for Gastric Cancer. PloS one. 2016;11(12):e0168119.

22. Uchino S, Kellum JA, Bellomo R, Doig GS, Morimatsu H, Morgera S, Schetz M, Tan I, Bouman C, Macedo $\mathrm{E}$, et al. Acute renal failure in critically ill patients: a multinational, multicenter study. JAMA: the journal of the American Medical Association. 2005;294(7):813-8.

23. Sun LY, Wijeysundera DN, Tait GA, Beattie WS. Association of intraoperative hypotension with acute kidney injury after elective noncardiac surgery. Anesthesiology. 2015;123(3):515-23. 
24. Walsh M, Devereaux PJ, Garg AX, Kurz A, Turan A, Rodseth RN, Cywinski J, Thabane L, Sessler DI. Relationship between intraoperative mean arterial pressure and clinical outcomes after noncardiac surgery: toward an empirical definition of hypotension. Anesthesiology. 2013;119(3):507-15.

25. Hallqvist L, Granath F, Huldt E, Bell M. Intraoperative hypotension is associated with acute kidney injury in noncardiac surgery: An observational study. Eur J Anaesthesiol. 2018;35(4):273-9.

26. Wu X, Jiang Z, Ying J, Han Y, Chen Z. Optimal blood pressure decreases acute kidney injury after gastrointestinal surgery in elderly hypertensive patients: A randomized study: Optimal blood pressure reduces acute kidney injury. J Clin Anesth. 2017;43:77-83.

27. Kristensen SD, Knuuti J, Saraste A, Anker S, Botker HE, Hert SD, Ford I, Gonzalez-Juanatey JR, Gorenek B, Heyndrickx GR, et al. 2014 ESC/ESA Guidelines on non-cardiac surgery: cardiovascular assessment and management: The Joint Task Force on non-cardiac surgery: cardiovascular assessment and management of the European Society of Cardiology (ESC) and the European Society of Anaesthesiology (ESA). European heart journal. 2014;35(35):2383-431.

\section{Figures}


Figure 1

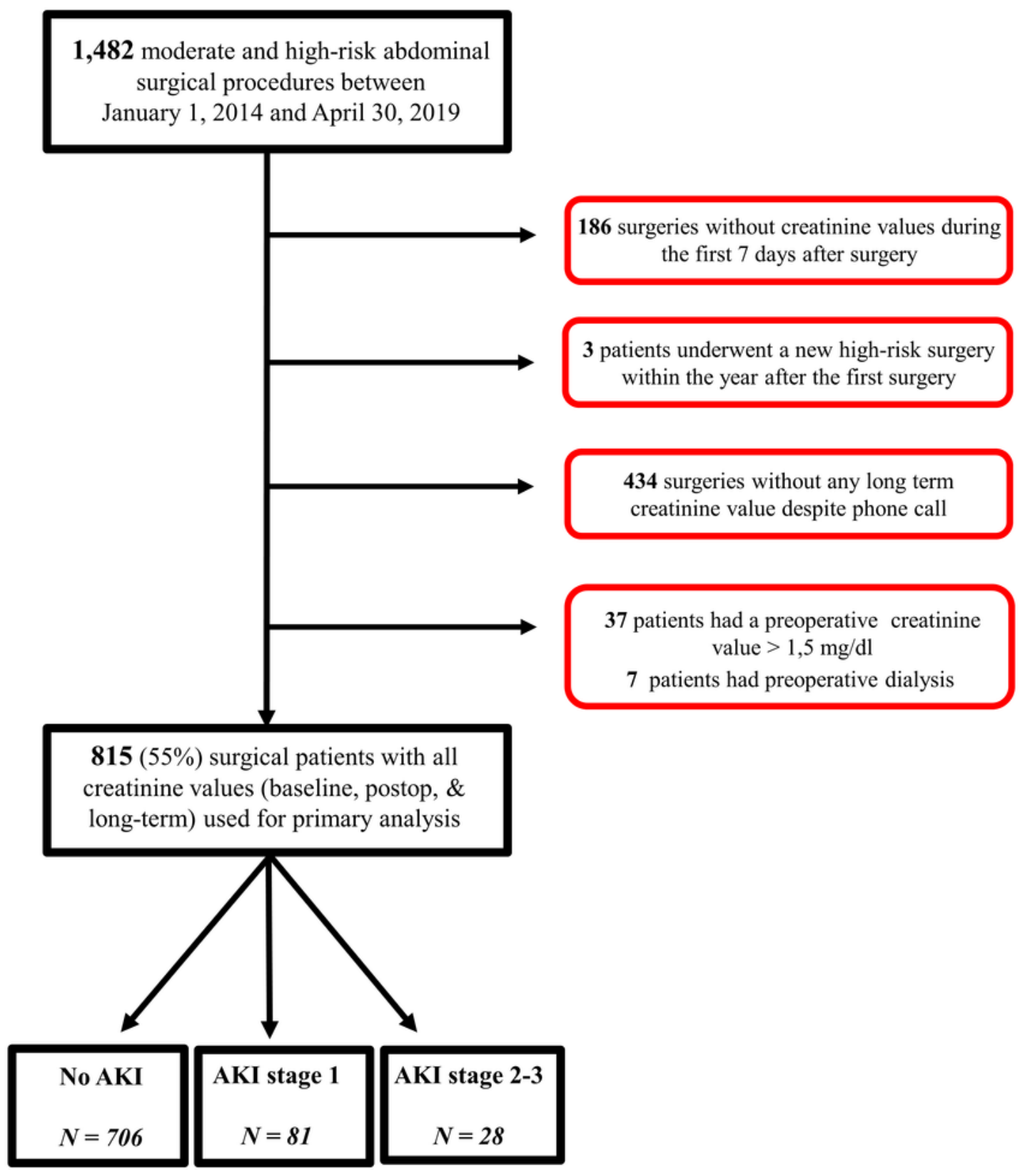

\section{Figure 1}

Enrollment flow chart. AKI: acute kidney injury 


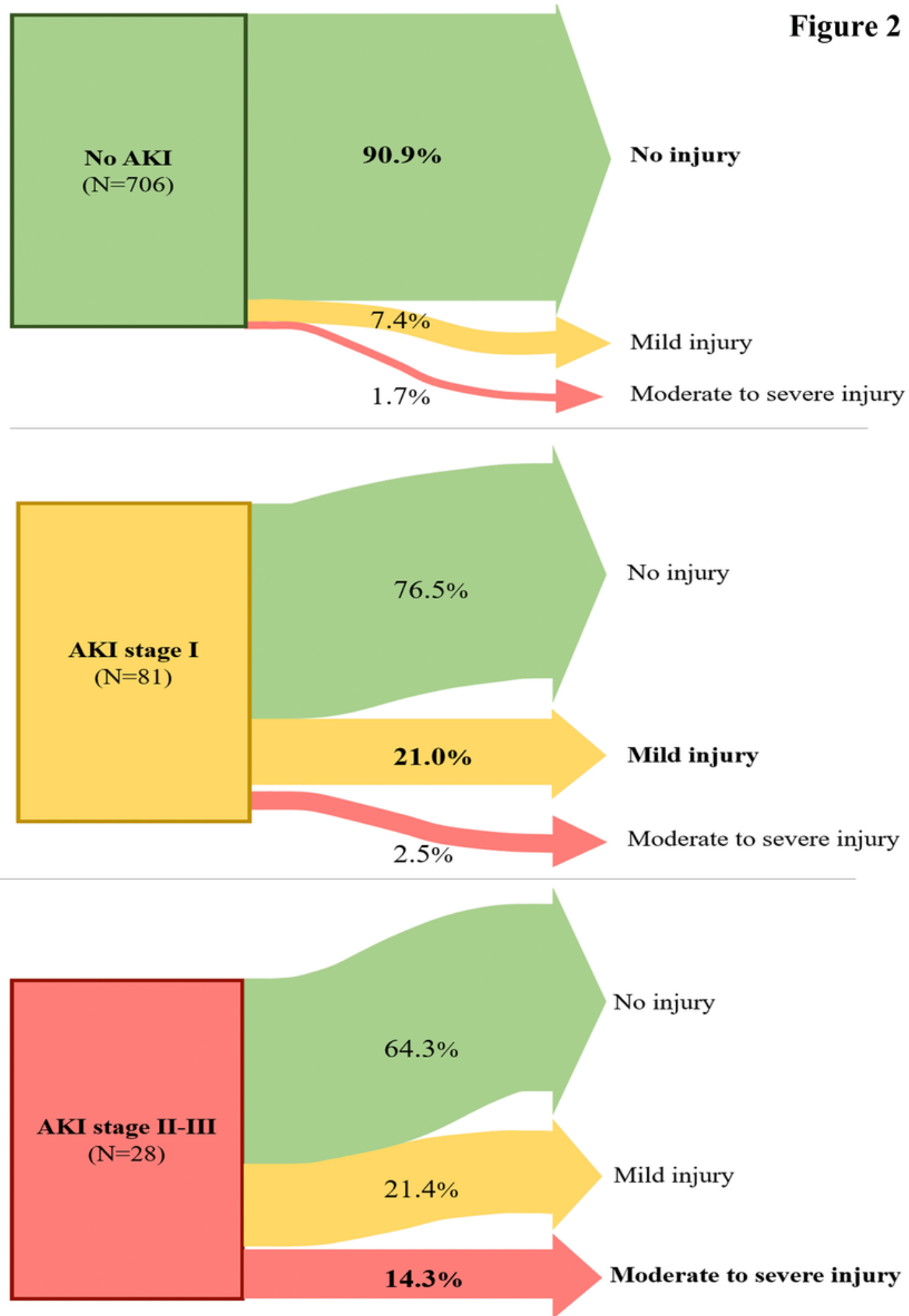

\section{Figure 2}

Renal outcomes one year after surgery according to postoperative acute kidney injury (AKI) stage. 